\title{
The Development of the Turkish Craving for Online Shopping Scale: A Validation Study
}

\author{
Mustafa Savci $^{1} \cdot$ Erol Ugur $^{2} \cdot$ Mustafa Ercengiz $^{3} \cdot$ Mark D. Griffiths $^{4}$ (D)
}

Accepted: 15 January 2021/Published online: 29 March 2021

(C) The Author(s) 2021

\begin{abstract}
In the present study, the Turkish version of the Craving for Online Shopping Scale (TCOSS) was developed by modifying items on the Penn Alcohol Craving Scale (PACS). The sample comprised 475 adult volunteers (233 women and 242 men) from three different non-clinical samples recruited online. The structure validity of the TCOSS was examined utilizing exploratory factor analysis (EFA), confirmatory factor analysis (CFA), and criterion validity testing. The EFA showed that the TCOSS had a unidimensional structure that explained $80 \%$ of the total variance. The five-item unidimensional structure of the TCOSS then underwent further testing using two different samples. First, the structure of the TCOSS was tested using CFA, which confirmed the unidimensional factor structure. Second, measurement invariance of the TCOSS was conducted through structural invariance, metric invariance, and scalar invariance across different samples. This demonstrated the TCOSS had measurement invariance across different samples (CFA and criterion validity samples). Criterion validity of the TCOSS was tested using the Internet Addiction Test-Short Form, Brief Self-Control Scale, Compulsive Online Shopping Scale, Positive and Negative Affect Schedule, and self-reported personal information. According to the criterion validity results, the TCOSS assessed the structure it targets. Cronbach's $\alpha$ internal consistency coefficients of the TCOSS were .94 in the EFA sample, .94 in the CFA sample, and .96 in the criterion validity sample. When validity and reliability analysis of the TCOSS are considered as a whole, it is concluded that the TCOSS is a valid and reliable scale for assessing craving for online shopping among online shoppers.
\end{abstract}

Keywords Online shopping · Online shopping addiction · Craving · Online shopping craving

Increased access to technology and the rapid advancement of Internet technology allow online shoppers to eliminate the limits of in-store shopping so that they can use their time flexibly to go shopping anytime, anywhere, 24/7. Moreover, the development of wireless networks and

Mark D. Griffiths

mark.griffiths@ntu.ac.uk

Extended author information available on the last page of the article 
intelligent mobile devices has facilitated online shopping (Tang et al. 2014). Coupled with this, online shopping has also increased. The increase in online shopping rates continues year by year. E-retail sales accounted for $7.4 \%$ in $2015,8.6 \%$ in $2016,10.2 \%$ in 2017 , and $11.9 \%$ in 2018 of all retail sales worldwide (Clement 2018). It is expected to reach $17.5 \%$ in 2021 (Clement 2018). In recent years, online shopping has also increased in Turkey (where the present study was carried out). Among the Turkish population (aged 16-74 years), online shopping accounted for $20.9 \%$ in 2016, 24.9\% in 2017, and 29.3\% in 2018 (Turkish Statistical Institute 2017).

As the amount of online shopping has increased, disorders related to online shopping have also increased. In the psychological literature, disorders arising from online shopping have been conceptualized including shopping addiction (Andreassen et al. 2015), online shopping addiction (Doğan-Keskin and Günüç 2017; Kaur et al. 2019; Rose and Dhandayudham 2014; Tanoto 2019; Zhao et al. 2017), compulsive online shopping (Manchiraju et al. 2017), pathological buying online (Trotzke et al. 2015), compulsive buying behavior (Granero et al. 2016; Maraz et al. 2016), and compulsive shopping (Hartston 2012). Although there are differences in conceptualization, there appear to be common criteria for online shopping addiction. Authors such as Griffiths (2005) have postulated that addictions consist of a number of common components. Most of the conceptualizations underline salience, mood modification, tolerance, withdrawal symptoms, conflict, and relapse (Savci and Griffiths 2019a, 2019b). Although online shopping addiction is not formally classified in the fifth edition of the Diagnostic and Statistical Manual of Mental Disorders (DSM-5; American Psychiatric Association [APA] 2013), it has been termed as a behavioral addiction in the literature (Grant et al. 2010; Holden 2010; Maraz et al. 2016; Rosenberg and Feder 2014; Uğur 2019; Weinstein et al. 2016). According to Marks' (1990) conceptualization, online shopping can be viewed as a behavioral addiction. Trotzke et al. (2015) also viewed pathological buying online as a specific form of Internet addiction, which is also a type of behavioral addiction.

Behavioral addictions are clinical phenomena in which repetitive (and often impulsive) behaviors occur, with negative effects on the individuals' and their relatives' lives (Villella et al. 2011). Behavioral addictions are similar to substance addictions in many ways including natural history, phenomenology, tolerance, comorbidity, overlapping genetic contribution, neurobiological mechanisms, and response to treatment (Grant et al. 2010; Griffiths 2005). Addiction professionals view specific nonsubstance behaviors such as problematic gambling, Internet use, video-game playing, sex, eating, and shopping as bearing resemblance to substance addictions (Griffiths 2005; Sauvaget et al. 2017; Yau and Potenza 2015). The mechanisms of substance and nonsubstance addictions have common characteristics. Some of these are excessive time spent in the behavior, repeated unsuccessful attempts to cut down or stop the behavior, diminished control over the behavior, tolerance, withdrawal, and adverse psychosocial consequences (Bozkurt et al. 2016; Grant et al. 2010; Griffiths 2005). Similar to chemical or substance addictions, behavioral addictions can also involve also an urge or craving before engaging in the addictive behavior (Grant et al. 2010; Griffiths 2005). The presence of craving among individuals with a propensity for online pathological buying emphasizes that online shopping addiction can be placed within the category of nonsubstance/behavioral addictions (Trotzke et al. 2015).

Online shopping addiction has been defined according to different perspectives and has no single definition. Online shopping addiction has been defined as problematic excessive online shopping comprising the following: (i) compulsive buying, (ii) the experience of uncontrollable urge to buy, (iii) purchasing goods even though they are not needed, (iv) experiences of post-purchase guilt, (v) getting upset when online shopping is not possible, (vi) having 
difficulties in reducing online shopping, (vii) suffering from overspending and financial problems, and (viii) harming relationships (Faber 1992; Joukanen 2019; Kaur et al. 2019; Kukar-Kinney et al. 2016; Maraz et al. 2016; Müller et al. 2019; Trotzke et al. 2019). Research conducted into online shopping addiction has found that shopping addiction is related to psychopathology (Volpe et al. 2015), sensitivity to reward (Volpe et al. 2015), lack of selfcontrol (Luo et al. 2018), low self-esteem, low self-regulation (Rose and Dhandayudham 2014), depression (Andreassen et al. 2015), binge eating disorder (Müller et al. 2015), problematic Internet use (Tao et al. 2019), and craving to buy (Trotzke et al. 2019). Based on the aforementioned research findings, it can be said that online shopping addiction has a broad etiological spectrum and that further empirical research is required to determine universal diagnostic criteria for online shopping addiction.

Online shopping enables individuals to buy anywhere and anytime and allows for the expansion of shopping alternatives beyond traditional methods that may be more time consuming (Shanthi and Desti 2015). In online shopping, individuals have the opportunity to use variety of facilities that motivate them to purchase at competitive prices, instant comparison of products, product variety, payment advantages, time saving, and shipping facilities. Based on the study of Trotzke et al. (2019), it can be said that these features of online shopping can induce individuals to crave online shopping. The urge or craving for shopping has been referred to in addiction literature (Blaine et al. 2018), and inability to control craving is one of the symptoms of addiction (Leung and Liang 2019). In addition, craving is considered as an important factor in the development and maintenance of behavioral addictions similar to substance addictions and conceptualized as the strong desire to engage in a specific behavior (Kyrios et al. 2018). More generally, craving is defined as "a strong desire/ urge" to use a substance (American Psychiatric Association, 2013).

In addition to research related to substance addictions, a considerable amount of research has been conducted to clarify the role of craving in behavioral addictions in recent years (e.g., Starcke et al. 2018; Trotzke et al. 2019). The concept of craving has started to play an important role in behavioral addictions (Fernandez et al. 2020) and some problematic behaviors such as social media addiction (Turel and Bechara 2016), gambling addiction (Cornil et al. 2019), problematic Internet pornography use (Allen et al. 2017), problematic online sexual activities (Chen et al. 2018), problematic eating (Joyner et al. 2015), Internet gaming disorder (Dong et al. 2020), and online shopping addiction (Andreassen et al. 2015; Tanoto 2019). Therefore, it can be said that craving constitutes one of the defining features of many behavioral addictions and is not limited to substance abuse and dependence.

There are several instruments in the literature that assess disorders relating to both online and offline shopping including the Online Shopping Addiction Scale (Zhao et al. 2017), Compulsive Online Shopping Scale (Manchiraju et al. 2017), Bergen Shopping Addiction Scale (Andreassen et al. 2015), Compulsive Buying Scale (Ridgway et al. 2008), and Compulsive Buying Follow-up Scale (Mattos de et al. 2019). There are also instruments related to craving for shopping in the literature. Starcke et al. (2012) modified the Drug and Alcohol Questionnaire (DAQ; Love et al. 1998) to create the Modified Craving Questionnaire (MCQ) to assess baseline craving for shopping. However, the validity and reliability studies of the MCQ and the Cronbach $\alpha$ internal consistency coefficient were not reported. Additionally, the MCQ assesses the craving for offline shopping, not online shopping. Therefore, more robust scales related to craving for online shopping are needed with greater reliability and validity assessments.

Clinical and epidemiological research studies have consistently shown that behavioral addictions are associated with a wide range of psychiatric disorders (Varo et al. 2019). Craving 
can drive addictive behaviors by increasing the salience of the desired behavior and by occupying the inhibition brain system. Consequently, individuals cannot properly engage in behavior control (Noël et al. 2013). Individuals with craving reactions continue to buy things despite the negative consequences of excessive shopping (Trotzke et al. 2019). When considering the importance of craving in behavioral addictions (and specifically in online shopping addiction), there is need for a robust instrument to assess it. In the related literature, there are no specific scales that assess the craving for online shopping. In this context, valid and reliable instruments that assess craving for online shopping can contribute to increasing the quality of research into craving for online shopping including cross-cultural studies. Such measurement tools could contribute to research related to the diagnosis, prevention, and treatment of problematic behaviors related to online shopping. Therefore, the main aims of the present study were to develop the Craving for Online Shopping Scale and to conduct validity and reliability studies of it.

For the main aim, the Turkish version of the Penn Alcohol Craving Scale (PACS) developed by Flannery et al. (1999) was adapted and validated to assess craving for online shopping among online shoppers. The PACS is a multi-item, single-factor scale that is quickly and easily administered. The first three items concern the frequency, intensity, and duration of thoughts about drinking alcohol. The fourth item asks individuals to rate their ability to resist drinking if alcohol is available. The final item asks individuals to rate their overall average craving for alcohol during the previous week. A once-a-month assessment may provide an inaccurate picture of craving, because the time frame may simply be too long for a person to accurately remember or average higher craving status. A weekly assessment appears to be an ideal period of time for assessing craving, because it may capture a range of craving states from very mild to quite intense (Flannery et al. 1999).

\section{Methods}

\section{Participants}

The study comprised 475 adult participants (233 women and 242 men) from three different non-clinical samples recruited online. The structure validity of the TCOSS was examined utilizing exploratory factor analysis (EFA), confirmatory factor analysis (CFA), and criterion validity testing. The EFA sample comprised 135 participants (66 females and 69 males), the CFA sample comprised 131 participants (68 females and 63 males), and the criterion validity sample comprised 209 participants (99 females and 110 males). Demographic information of the three study groups is presented in Table 1 .

\section{Materials}

Turkish Craving for Online Shopping Scale (TCOSS) The TCOSS scale was modified from the five-item PACS developed by Flannery et al. (1999). In the present study, PACS was adapted to Turkish as TCOSS by replacing the word "alcohol" with the words "online shopping." Here, the protocol for the modified PACS followed previous studies that developed craving scales for social media (Savci and Griffiths 2019a), Internet gaming (Savci and Griffiths 2019b), and smartphone use (Savci 2019) that replaced the word "drinking" with "social media," "Internet gaming," and "smartphone," respectively. 
Table 1 Demographic information of the three study groups

\begin{tabular}{|c|c|c|c|c|c|c|c|}
\hline & \multicolumn{2}{|c|}{ EFA sample } & \multicolumn{2}{|c|}{ CFA sample } & \multicolumn{2}{|c|}{ Criterion validity sample } \\
\hline & & $\mathrm{N}$ & $\%$ & $\mathrm{~N}$ & $\%$ & $\mathrm{~N}$ & $\%$ \\
\hline \multirow[t]{2}{*}{ Sex } & Females & 66 & 48.9 & 68 & 52 & 99 & 47 \\
\hline & Males & 69 & 51.1 & 63 & 48 & 110 & 53 \\
\hline \multicolumn{2}{|l|}{ Age } & \multicolumn{2}{|c|}{$\begin{array}{l}18-51 \text { years, } \\
\bar{X}=27.05\end{array}$} & \multicolumn{2}{|c|}{$\begin{array}{l}18-55 \text { years, } \\
\bar{X}=25.94\end{array}$} & \multicolumn{2}{|c|}{$\begin{array}{l}18-48 \text { years, } \\
\bar{X}=24.07\end{array}$} \\
\hline \multicolumn{2}{|c|}{ Daily online shopping duration } & \multicolumn{2}{|c|}{$\begin{array}{l}10-240 \mathrm{~min} \\
\bar{X}=36.59\end{array}$} & \multicolumn{2}{|c|}{$\begin{array}{l}5-200 \mathrm{~min} \\
\bar{X}=36.69\end{array}$} & \multicolumn{2}{|c|}{$\begin{array}{l}10-220 \mathrm{~min} \\
\bar{X}=37.81\end{array}$} \\
\hline \multicolumn{2}{|c|}{ Online shopping history } & \multicolumn{2}{|c|}{$\begin{array}{l}1-11 \text { years, } \\
\bar{X}=3.96\end{array}$} & \multicolumn{2}{|c|}{$\begin{array}{l}1-13 \text { years, } \\
\bar{X}=3.80\end{array}$} & \multicolumn{2}{|c|}{$\begin{array}{l}1-8 \text { years, } \\
\bar{X}=3.03\end{array}$} \\
\hline \multicolumn{2}{|c|}{ The number of websites regularly used for shopping } & \multicolumn{2}{|c|}{$\begin{array}{l}1-7 \text { websites, } \\
\bar{X}=2.35\end{array}$} & \multicolumn{2}{|c|}{$\begin{array}{l}1-10 \text { websites, } \\
\bar{X}=2.88\end{array}$} & \multicolumn{2}{|c|}{$\begin{array}{l}1-9 \text { websites, } \\
\bar{X}=2.27\end{array}$} \\
\hline \multicolumn{2}{|c|}{ Number of online shopping in the past week } & \multicolumn{2}{|c|}{$\begin{array}{l}1-7 \text { times, } \\
\bar{X}=2.58\end{array}$} & \multicolumn{2}{|c|}{$\begin{array}{l}1-8 \text { times, } \\
\bar{X}=2.09\end{array}$} & \multicolumn{2}{|c|}{$\begin{array}{l}1-6 \text { times, } \\
\bar{X}=2.11\end{array}$} \\
\hline \multicolumn{2}{|c|}{ Total } & \multicolumn{2}{|c|}{135} & \multicolumn{2}{|c|}{131} & \multicolumn{2}{|l|}{209} \\
\hline
\end{tabular}

First of all, PACS items and instruction were translated into Turkish by a group of researchers who were fluent in English and Turkish. Subsequently, the items translated into Turkish were back translated into English by another group of researchers who were fluent in English and Turkish following international standardized protocols (Beaton et al. 2000). Consequently, the consistency between the items translated into English and the original PACS was evaluated. Finally, a draft form for the PACS was created by evaluating the forms from the two groups of researchers. Consequently, the language validity of PACS was completed. Following this, the translated PACS was revised to the TCOSS. In the TCOSS, the words "online shopping" were used instead of the word "drinking." See Appendix 1 for the Turkish version and Appendix 2 for the English version of the TCOSS.

Internet Addiction Test-Short Form The IAT-SF, originally developed by Young (1998), shortened by Pawlikowski et al. (2013), and adapted to Turkish by Kutlu et al. (2016), was used to assess Internet addiction. The scale has 12 items (e.g., "How often do you find that you stay on-line longer than you intended?" and "How often do you become defensive or secretive when anyone asks you what you do on-line?") responded to on a five-point Likert scale ( $1=$ never, $5=$ always) and is unidimensional. Higher scores obtained from the scale indicate higher levels of Internet addiction (Kutlu et al. 2016). In the present study, Cronbach's alpha was .84 .

Brief Self-Control Scale The BSCS was developed by Tangney et al. (2004) and adapted into Turkish by Nebioglu et al. (2012). The scale has nine items responded to on a five-point Likert scale ( $1=$ not suitable at all, $5=$ completely suitable) comprising two sub-dimensions (impulsiveness and self-discipline). As a result of CFA, the BSCS showed relatively acceptable fit in a Turkish sample (Nebioglu et al. 2012). Cronbach's $\alpha$ internal consistency reliability coefficients of the BSCS ranged between .81 and .87. High scores indicate a high level of impulsivity on the impulsiveness sub-dimension. Similarly, high scores on the self-discipline sub-dimension indicate a high level of self-discipline (Nebioglu et al. 2012). In the present study, Cronbach's alpha coefficient was .79. 
Compulsive Online Shopping Scale Manchiraju et al. (2017; Turkish version: Bozdag and Yalcinkaya-Alkar 2018) modified the Bergen Shopping Addiction Scale (developed by Andreassen et al. (2015) as the Compulsive Online Shopping Scale. The COSS has 28 items (e.g., "Shopping/buying is the most important thing in my life" and "I feel bad if I for some reason am prevented from shopping/buying things") responded to on a five-point Likert scale $(0=\mathrm{I}$ strongly disagree, $4=$ absolutely I agree) and five sub-dimensions (problem-conflictrelapse, salience, mood modification, withdraw, and tolerance). The COSS has acceptable levels of validity and reliability (Bozdag and Yalcınkaya-Alkar 2018). High scores indicate high levels of online compulsive shopping behavior. In the present study, Cronbach's alpha was .86 .

Positive and Negative Affect Schedule The Positive and Negative Affect Scale, developed by Watson et al. (1988) and adapted to Turkish by Gençöz (2000), includes two subdimensions for assessing positive and negative emotions. The scale contains 20 items (e.g., "strong" and "hostile") that identify 10 positive and 10 negative emotions and is responded to using a five-point Likert scale ( $1=$ too little or nothing, $5=$ too much). PANAS has acceptable levels of validity and reliability (Gençöz 2000). High scores indicate a high level of positive affect in the positive affect sub-dimension. Similarly, high scores on the negative affect subdimension indicate a high level of negative affect. In the present study, Cronbach's coefficients were .78 for positive affect and .81 for negative affect.

\section{Procedure and Ethics}

In the present study, permission was obtained for data collection by the first author's university ethics committee. Furthermore, each phase of the study was carried out in accordance with the Declaration of Helsinki. In the present study, the data were collected using online forms (i.e., a survey utilizing Google Forms). The link to the survey was shared then on social media (WhatsApp) utilizing the snowball sampling method. The inclusion criteria to be included in the study were that participants had to have engaged in (i) online shopping for the past year and (ii) online shopping at least once in the past week.

\section{Data Analysis}

The structural validity of the TCOSS was examined utilizing exploratory factor analysis (EFA), confirmatory factor analysis (CFA), and criterion validity testing. Further analysis compared the single-factor structure of the TCOSS to the CFA and criterion validity testing samples. The analysis compared the TCOSS model with multi-group analysis. The data were evaluated to see if they were suitable for these analyses. The analyses examined (i) KaiserMeyer-Olkin (KMO) coefficient and Bartlett's sphericity test for the EFA and (ii) univariatemultiple normality, multicollinearity, and sample size for the CFA, as well as correlation analyses and multi-group analysis (see the "Results" section for the statistical analyses). The data were found to be suitable for EFA, CFA, multi-group analysis, and criterion validity testing.

The Kaiser-Meyer-Olkin (KMO) coefficient was .90, and the Bartlett sphericity test was as follows: $\chi^{2}=588.636$ and $p<.001$. These results showed that the data were suitable for EFA. The CFA dataset was first examined in terms of univariate and multivariate normality, as well 
as sample size sufficiency. The skewness and kurtosis coefficients for the items were between -1 and +1 . Therefore, the dataset had univariate normality. The dataset was then analyzed for multivariate normality. First, the Mahalanobis distance was examined. As a result of the analysis, nine extreme values were deleted from the dataset and multiple normality was examined. As a result of the analysis, the CFA dataset had multiple normality (multivariate kurtosis $=4.845$ and multivariate critical ratio $=3.314$ ). Multicollinearity problems occur when the binary correlations between the variables are greater than .90 (Cokluk et al. 2012). In the present study, the binary correlation between the items was lower than .90 . Therefore, there were no multicollinearity problems in the CFA dataset. Finally, some researchers suggest a sample size of around 150 for a simple CFA model with normal observed variables and/or at least 10-20 participants per scale item (Comrey 1988; Muthén and Muthén 2002). The CFA sample comprised 131 participants (68 females and 63 males) for a five-item scale. Therefore, the sample size was sufficient for CFA in this instance.

The criterion validity dataset was examined in terms of univariate-multiple normality, multicollinearity, and sample size. The skewness and kurtosis coefficients of each item were between -1 and +1 in the criterion validity dataset. This indicated univariate normality. Multivariate normality was then examined. Considering the Mahalanobis distance, 19 extreme values were deleted. As a result of the analysis, the criterion validity dataset had multiple normality (multivariate kurtosis $=4.932$ and multivariate critical ratio $=4.261$ ). There was no correlation over .90 in the binary correlations of the scale items. Therefore, there were no multicollinearity problems in the dataset. Finally, the criterion validity sample comprising 209 participants was of sufficient size based on the aforementioned guidelines (Comrey 1988; Muthén and Muthén 2002).

The maximum likelihood method was used for the CFA. In order to assess the model fit, fit indices such chi-squared $\left(\chi^{2}\right)$, root mean square error of approximation (RMSEA), goodnessof-fit index (GFI), adjusted goodness-of-fit index (AGFI), confirmatory fit index (CFI), incremental fit index (IFI), and Tucker-Lewis index (TLI) (as outlined in Table 2) were considered. The criterion validity of the TCOSS was tested using the IAT-SF, BSCS, COSS, PANAS, and self-reported personal information. The reliability of the TCOSS was assessed with Cronbach $\alpha$ internal consistency coefficients. SPSS and AMOS programs were used to analyze the data.

\section{Results}

\section{Scale Validity}

Exploratory factor analysis (EFA) The EFA carried out on the TCOSS utilized data collected from 135 participants (66 females and 69 males). The Kaiser-Meyer-Olkin (KMO) coefficient was .90 , and the Bartlett sphericity test was as follows: $\chi^{2}=588.636$ and $p<.001$. These results showed that the dataset was suitable for EFA, which used principal component analysis. Principal components analysis is frequently used in order to select suitable items and determine subscales (if any) in scale development or adaptation studies (Tabachnick and Fidell 2013). The EFA demonstrated a unidimensional structure (eigenvalue $=4.008$ ) that explained $80 \%$ of the total variance. The line graph (Fig. 1) shows that TCOSS has a single-factor structure. Finally, analysis showed that the factor loading values of the TCOSS ranged from .82 to .93 . 
Table 2 Goodness-of-fit indices and acceptable limits

\begin{tabular}{ll}
\hline Indices & Acceptable limits \\
\hline$\chi^{2 / d f}$ & $\leq 5$ acceptable fit, $\leq 3$ perfect fit \\
RMSEA & $\leq 0.10$ weak fit, $\leq 0.08$ good fit, $\leq 0.05$ perfect fit \\
GFI & $.85-.89$ acceptable fit, $\geq .90$ good fit \\
AGFI & $.85-.89$ acceptable fit, $\geq .90$ good fit \\
CFI & $\geq .90$ acceptable fit, $\geq .95$ good fit, $\geq .97$ perfect fit \\
IFI & $\geq .90$ acceptable fit, $\geq .95$ good fit, $\geq .97$ perfect fit \\
TLI (NNFI) & $\geq .90$ acceptable fit, $\geq .95$ good fit \\
\hline
\end{tabular}

(Brown, 2006; Cokluk et al. 2012; Hu \& Bentler, 1999; Kelloway, 2015; Kline, 2011; Raykov \& Marcoulides, 2008; Meydan \& Șeșen, 2011; Schumacker \& Lomax, 2004; Schermelleh-Engel et al., 2003, Sümer, 2000; Şimșek, 2007; Tabachnick and Fidell 2013; Thompson, 2004; as cited in, Savci and Aysan 2019) $\chi^{2}$ chisquared, $d f$ degrees of freedom, $R M S E A$ root mean square error of approximation, $G F I$ goodness-of-fit index, $A G F I$ adjusted goodness-of-fit index, CFI confirmatory fit index, IFI incremental fit index, TLI Tucker-Lewis index, NNFI non-normed fit index

Confirmatory Factor Analysis The five-item unidimensional structure of the TCOSS underwent CFA. As a result of the analysis, the unidimensional factor structure of the TCOSS was confirmed in the CFA $\left(\chi^{2}=7.027, \mathrm{df}=5, \chi^{2} / \mathrm{df}=.219, \mathrm{RMSEA}=.056\right.$, GFI $=.98$, $\mathrm{AGFI}=.94, \mathrm{CFI}=.99, \mathrm{IFI}=.99$ and TLI $(\mathrm{NNFI})=.99)$. The standardized regression coefficients of the TCOSS ranged between .70 and .92 . The CFA results are shown in Table 3.

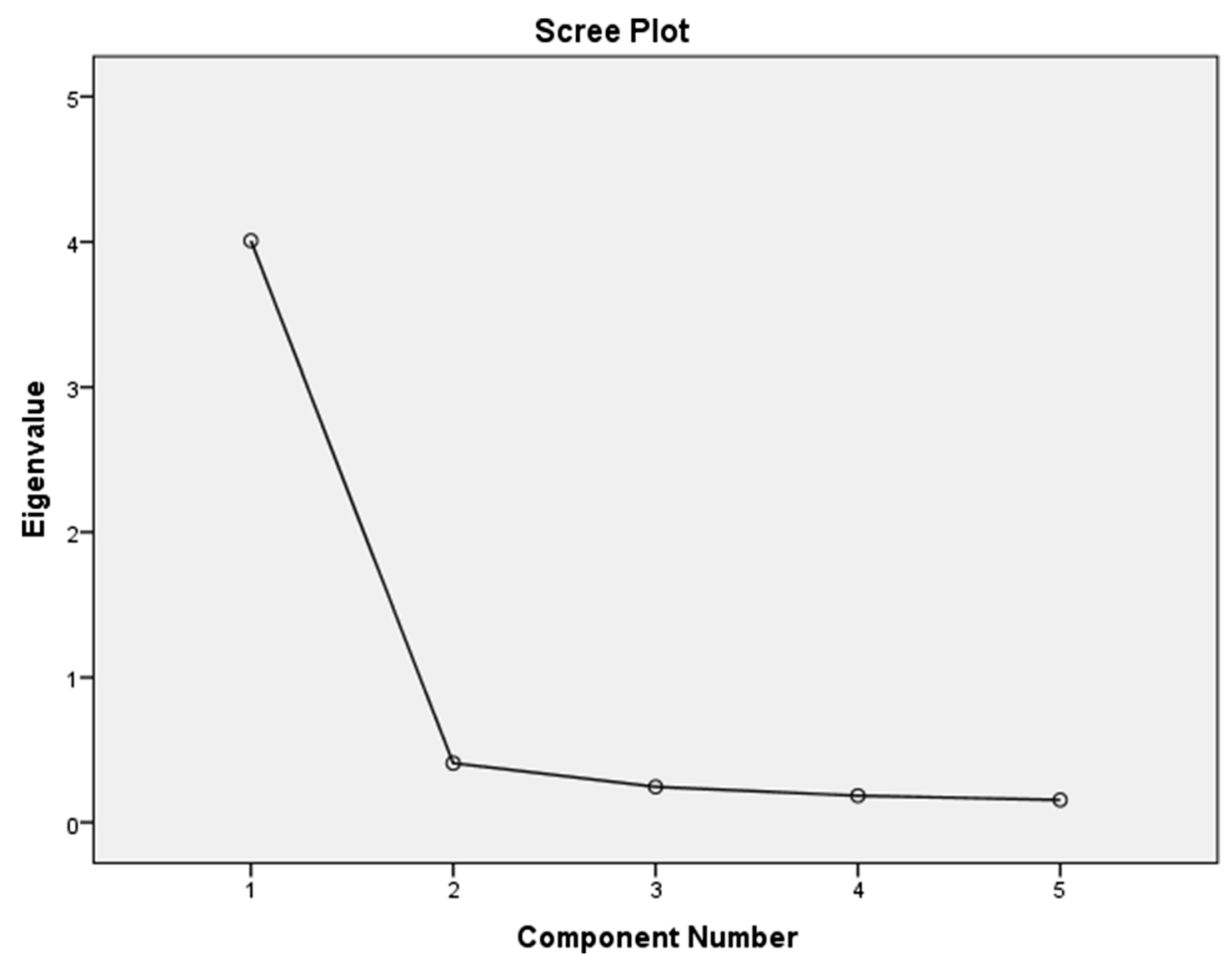

Fig. 1 The scree plot of the TCOSS. 
In addition, measurement invariance of TCOSS across gender in the CFA sample was also tested by multi-group analysis. As a result of the analysis, it was determined that TCOSS was not significantly different in female and male participants (in terms of structural invariance and metric invariance, although not in terms of scalar invariance). More specifically, structural invariance was tested over the baseline model in which any parameter value was not equalized. As a result of the analysis, the fit indices had acceptable values. Therefore, the TCOSS was structurally equal in terms of female and male participants. In order to test the metric invariance, the factor loadings of the TCOSS items were equalized between the groups, and the results of the multi-group CFA were compared with the structural model. Models were compared considering $\chi^{2}$ and CFI values. For metric invariance, the $\chi^{2}$ value is expected to be statistically non-significant and the CFI value to be less than .01. As a result of the analysis, metric invariance was supported $\left(\chi^{2}=3.743, p=.587\right.$, and CFI =.001). The factor loadings of the TCOSS items were equivalent in terms of female and male participants. Finally, scalar invariance was tested. The analysis showed that scalar invariance was not supported $\left(\chi^{2}=\right.$ $16.844, p=.005$, and $\mathrm{CFI}=.017)$. Results relating to measurement invariance of TCOSS across gender are presented in Table 4.

Further analysis compared the single-factor structure of the TCOSS to the samples of CFA and criterion validity. For this purpose, the analysis compared the TCOSS model with multigroup analysis. Measurement invariance of the TCOSS was conducted through structural invariance, metric invariance, and scalar invariance. These were analyzed by combining the CFA and criterion validation samples. Structural invariance results showed that the factorial structure of TCOSS was equivalent in terms of two samples. Metric invariance results show that TCOSS's factor loadings were equivalent in the CFA and criterion validity samples $\left(\chi^{2}=\right.$ $1.120, p=.952, \mathrm{CFI}=.003)$. Finally, scalar invariance was examined. Although $\chi^{2}$ was statistically significant $\left(\chi^{2}=14.036, p=.015\right)$, the CFI was acceptable $(\mathrm{CFI}=.005)$. Therefore, the TCOSS has scalar invariance. Overall, the TCOSS had measurement invariance across different samples (CFA and criterion validity samples). Results relating to measurement invariance of TCOSS across samples are presented in Table 5.

Criterion Validity The criterion validity testing of the TCOSS utilized data from 209 participants (99 females and 110 males) by utilizing the IAT-SF (Internet addiction), BSCS (selfdiscipline, impulsiveness), COSS (problem-conflict-relapse, salience, mood modification, withdraw, and tolerance), PANAS (positive affect and negative affect), and self-reported personal information (daily online shopping duration, online shopping history, the number of websites regularly used for shopping, and number of online shopping in the past week). Scores on the TCOSS were significantly associated with scores for Internet addiction $(r=.50$, $p<.01)$, self-discipline $(r=-.24, p<.01)$, impulsiveness $(r=.38, p<.01)$, problem-conflictrelapse $(r=.39, p<.01)$, salience $(r=.33, p<.01)$, mood modification $(r=.35, p<.01)$,

Table 3 The confirmatory factor analysis results of the TCOSS

\begin{tabular}{lllr}
\hline & $\lambda$ & $R^{2}$ & $t$ \\
\hline TCOSS $\rightarrow$ item 1 & .92 & .84 & 17.685 \\
TCOSS $\rightarrow$ item 2 & .95 & .91 & 20.207 \\
TCOSS $\rightarrow$ item 3 & .90 & .82 & 17.079 \\
TCOSS $\rightarrow$ item 4 & .70 & .48 & 9.903 \\
TCOSS $\rightarrow$ item 5 & .91 & .84 & \\
\hline
\end{tabular}


Table 4 Results of measurement invariance of the TCOSS across gender

\begin{tabular}{lrllllllll}
\hline & \multicolumn{1}{c}{$\chi^{2}$} & df & $p$ & CFI & RMSEA & GFI & AGFI & IFI & TLI (NNFI) \\
\hline Structural invariance & 18.896 & 10 & .042 & .99 .083 & .95 & .85 & .99 & .97 \\
Metric invariance & 3.743 & 5 & .587 & .001 & & & & \\
Scalar invariance & 16.844 & 5 & .005 & .017 & & & & \\
\hline
\end{tabular}

withdrawal $(r=.35, p<.01)$, tolerance $(r=.38, p<.01)$, positive affect $(r=-.21, p<.01)$, negative affect $(r=.40, p<.01)$, daily online shopping duration $(r=.39, p<.01)$, online shopping history $(r=.27, p<.01)$, the number of websites regularly used for shopping $(r=.24, p<.01)$, and number of online shopping in the past week $(r=.47, p<.01)$.

\section{Scale Reliability}

The reliability of the TCOSS was tested in the three different samples (EFA, CFA, and criterion validity) using Cronbach's $\alpha$ internal consistency coefficient. The Cronbach $\alpha$ internal consistency coefficients of the TCOSS were excellent across all three samples: .94 in the EFA sample, .94 in the CFA sample, and .96 in the criterion validity sample.

\section{Discussion}

In the present study, the Penn Alcohol Craving Scale (PACS) was modified to develop the Turkish Craving for Online Shopping Scale (TCOSS) and examined the validity and reliability of the TCOSS. Although scales relating to craving for shopping addiction exist, they do not report the psychometric properties and online assess craving for land-based shopping. Consequently, the TCOSS is an important addition to the field, particularly as it assesses an important and specific dimension of online shopping addiction (i.e., craving).

The construct validity of the TCOSS was examined using both EFA and CFA, and the criterion validity was examined through Internet addiction, self-discipline, impulsiveness, compulsive shopping, positive affect, negative affect, daily online shopping duration, online shopping history, the number of websites regularly used for shopping, and number of online shopping in the past week. The reliability of the TCOSS was examined by calculating the Cronbach $\alpha$ internal consistency reliability coefficient in three independent samples. The EFA found that the TCOSS has a unidimensional structure explaining $80 \%$ of the total variance. This variance is a very high, even for unidimensional scales. In essence, almost all craving for online shopping can be assessed with the TCOSS.

The structure as a result of EFA was further tested with CFA. As a result of the CFA, the single-factor structure of the TCOSS was confirmed with high fit index values. The five-item

Table 5 Results of measurement invariance of TCOSS across samples

\begin{tabular}{lrllllllll}
\hline & $\chi^{2}$ & df & $p$ & CFI & RMSEA & GFI & AGFI & IFI & TLI (NNFI) \\
\hline Structural invariance & 14.662 & 10 & .145 & .99 & 043 & .98 & .95 & .99 & .99 \\
Metric invariance & 1.120 & 5 & .952 & .003 & & & & & \\
Scalar invariance & 14.036 & 5 & .015 & .005 & & & & & \\
\hline
\end{tabular}


unidimensional structure of the TCOSS then underwent further testing using two different samples. First, the structure of the TCOSS was tested using CFA, which confirmed the unidimensional factor structure. Second, measurement invariance of the TCOSS was conducted through structural invariance, metric invariance, and scalar invariance across different samples, which demonstrated the TCOSS had measurement invariance across different samples (CFA and criterion validity samples). In addition, measurement invariance of TCOSS across gender in the CFA sample was also tested by multi-group analysis, and it had relative measurement invariance. According to the criterion validity results, the TCOSS appears to assess the construct it targets given the high and significant correlations with similar constructs. Finally, the Cronbach internal consistency reliability coefficient was excellent in all three samples tested (Buyukozturk 2010; Cokluk et al. 2012; Kline 1994; Tabachnick and Fidell 2013). Based on these many analyses, the TCOSS can be used by researchers to evaluate craving for online shopping among online shoppers. The TCOSS is a step toward specifically examining a specific and important facet of problematic online shopping. The TCOSS can be used in descriptive cross-sectional and longitudinal studies, especially among non-clinical samples. The TCOSS aims to assess the cravings of online shoppers in relation to their online shopping. Therefore, if it is possible to assess whether someone drinking alcohol can have an alcohol craving or not, it also appears to be the case that an individual's craving for online shopping can be assessed.

\section{Strengths, Limitations, and Future Research}

The TCOSS is one of the few scales assessing aspects of problematic online shopping. In addition, the TCOSS was developed by modifying the Penn Alcohol Craving Scale (PACS), a commonly used and well-known scale. The TCOSS has a (i) robust factor structure, which was confirmed among two independent samples following the initial EFA, and (ii) a high level of reliability found among three independent samples. The TCOSS's criterion validity was also comprehensively demonstrated. As a result of the analysis, it was found that TCOSS has the expected relationships with the constructs examined. The TCOSS's validity and reliability analysis was developed by recruiting online shoppers (i.e., individuals that had been online shopping for the past year and had been online shopping at least once in the past week). Therefore, the TCOSS was developed appropriately. Finally, the TCOSS is a unidimensional scale comprising just five items. Therefore, it is a scale with brevity that will help alleviate survey fatigue.

Despite the aforementioned advantages, the TCOSS also has some limitations. Firstly, the TCOSS is a self-report scale and self-report is open to well-known biases. Although TCOSS was developed with online shoppers, this is a non-clinical sample. In future studies, the validity and reliability of TCOSS need to be examined among individuals who are confirmed problematic online shoppers. Additionally, the reliability of TCOSS was only examined utilizing Cronbach $\alpha$ internal consistency coefficients. This analysis alone does not determine whether the TCOSS delivers consistent results over time. Therefore, future studies should include test-retest reliability to assess whether the TCOSS provides stable results over time. Finally, the validity and reliability analysis of the English version of the TCOSS has not been performed. The English items of the TCOSS were translated by researchers who were fluent in both English and Turkish. However, the authors are confident that the translated items are robust and that additional back translation would not result in any significant change to the wording in the TCOSS. However, validity and reliability analysis of the English items of the TCOSS should be performed in future studies. 


\section{Appendix 1}

Table 6 Online Alıșveriș Așerme Ölçeği (OAAÖ) (Turkish). Bu araștırma online alışveriș yapma isteğinizi değerlendirmek amaciyla gerçekleștirilmektedir. Lütfen her maddeyi dikkatlice okuyun ve son bir haftayı dikkate alarak, online alışveriș așermenizi (online alışveriș yapma isteğinizi) en iyi tanımlayan seçeneği ișaretleyin

1. Son bir haftayı dikkate aldığınızda, online alıșveriș yapmak ile ilgili ya da online alıșveriș yapmanın sizi ne kadar iyi hissettireceği ile ilgili ne sıklıkta düşündünüz?

Hiç (geçtiğimiz hafta içinde 0 defa)

(1) Nadiren (geçtiğimiz hafta içinde 1-2 defa)

(2) Ara sıra (geçtiğimiz hafta içinde 3-4 defa)

(3) Bazen (geçtiğimiz hafta içinde 5 ila 10 defa veya günde 1-2 defa)

(4) Siklıkla (geçtiğimiz hafta içinde 11-20 defa veya günde 2-3 defa)

(5) Çoğu zaman (geçtiğimiz hafta içinde 20-40 defa veya günde 3-6 defa)

(6) Neredeyse her zaman (geçtiğimiz hafta içinde 40 defadan fazla veya günde 6 defadan fazla)

2. Son bir haftayı dikkate aldığınızda, en șiddetli noktasında, online alıșveriș așermeniz ne kadar güçlüydü?

Hiç istek yoktu

(1) Önemsenmeyecek düzeyde, yani çok hafif istek

(2) Hafif istek

(3) Orta düzeyde istek

(4) Güçlü istek, fakat kolaylıkla kontrol edildi

(5) Güçlü istek ve kontrol edilmesi zor

(6) Güçlü istek ve kontrol edilemez

3. Son bir haftayı dikkate aldığınızda, online alıșveriș yapmak ile ilgili ya da online alıșveriș yapmanın sizi ne kadar iyi hissettireceği ile ilgili düșünmeye ne kadar zaman harcadınız? Hiç

(1) 20 dakikadan az

(2) 21-45 dakika

(3) 46-90 dakika

(4) 90 dakika -3 saat

(5) 3-6 saat arası

(6) 6 saatten daha fazla

4. Son bir haftayı dikkate aldığınızda, eğer online alıșveriş yapma imkânınız olduğunu bilseydiniz online alıșveriş yapmaya direnmek ne kadar zor olurdu?

Hiç zor olmazdi

(1) Çok hafif zor

(2) Hafif zor

(3) Orta zorlukta

(4) Çok zor

(5) Așırı zor

(6) Karșı koyamazdım

5. Önceki sorulara verdiğiniz cevapları aklınızda tutarak, lütfen son bir hafta için ortalama online alıșveriș așermenizi değerlendirin.

Hiç online alıșveriș yapma düșüncem olmadı ve hiç online alıșveriș yapma isteğim olmadı.

(1) Nadiren online alışveriş yapmayla ilgili düşündüm ve nadiren online alışveriş yapma isteğim oldu.

(2) Ara sıra online alışveriș yapmayla ilgili düșündüm ve ara sıra online alışveriș yapma isteğim oldu.

(3) Bazen online alıșveriș yapmayla ilgili düșündüm ve bazen online alıșveriș yapma isteğim oldu.

(4) Sıklıkla online alıșveriş yapmayla ilgili düșündüm ve sıklıkla online alıșveriș yapma isteğim oldu.

(5) Çoğu zaman online alışveriș yapmayla ilgili düșündüm ve çoğu zaman online alıșveriș yapma isteğim oldu.

(6) Neredeyse her zaman online alışveriş yapmayla ilgili düşündüm ve neredeyse her zaman online alışveriș yapma isteğim oldu. 


\section{Appendix 2}

Table 7 Craving for Online Shopping Scale (TCOSS). This research is carried out to evaluate your craving for online shopping (desire for online shopping). Please read the following questions and choose the option that suits you. Please consider the option for each question that best describes your craving for online shopping over the past week

1. In the past week, how often have you thought about online shopping or about how good online shopping would make you feel?

Never, that is, 0 times during this period of time.

(1) Rarely, that is, 1 to 2 times during this period of time.

(2) Occasionally, that is, 3 to 4 during this period of time.

(3) Sometimes, that is, 5 to 10 times during this period or 1 to 2 times a day.

(4) Often, that is, 11 to 20 times during this period or 2 to three times a day.

(5) Most of the time, that is, 20 to 40 during this period or 3 to 6 times a day.

(6) Nearly all of the time, that is, more than 40 times during this period or more than 6 times a day.

2. In the past week at its most severe point, how strong was your craving for online shopping? None at all.

(1) Slight, that is a very mild urge.

(2) Mild urge.

(3) Moderate urge.

(4) Strong urge, but easily controlled.

(5) Strong urge and difficult to control.

(6) Strong urge and uncontrollable.

3. In the past week, how much time have you spent thinking about online shopping or about how good online shopping would make you feel?

None at all.

(1) Less than $20 \mathrm{~min}$.

(2) $21-45 \mathrm{~min}$.

(3) $46-90 \mathrm{~min}$.

(4) $90 \mathrm{~min}-3 \mathrm{~h}$.

(5) Between 3 and $6 \mathrm{~h}$.

(6) More than $6 \mathrm{~h}$.

4. In the past week, how difficult would it have been to resist online shopping if you knew you had the opportunity to engage in online shopping?

Not difficult at all.

(1) Very mildly difficult.

(2) Mildly difficult.

(3) Moderately difficult.

(4) Very difficult.

(5) Extremely difficult.

(6) Would not be able to resist.

5. Keeping in mind your responses to the previous questions, please rate your overall average craving for online shopping during the past week.

Never thought about online shopping and never had the urge to online shopping.

(1) Rarely thought about online shopping and rarely had the urge to online shopping.

(2) Occasionally thought about online shopping and occasionally had the urge to online shopping.

(3) Sometimes thought about online shopping and sometimes had the urge to online shopping.

(4) Often thought about online shopping and often had the urge to online shopping.

(5) Thought about online shopping most of the time and had the urge to online shopping most of the time.

(6) Thought about online shopping nearly all of the time and had the urge to online shopping nearly all of the time. 


\section{Declarations}

Ethics Approval All procedures performed in this study involving human participants were in accordance with the ethical standards of the University's Research Ethics Board and with the 1975 Helsinki Declaration.

Consent to Participate Informed consent was obtained from all participants.

Conflict of Interest The authors declare no conflict of interest.

Open Access This article is licensed under a Creative Commons Attribution 4.0 International License, which permits use, sharing, adaptation, distribution and reproduction in any medium or format, as long as you give appropriate credit to the original author(s) and the source, provide a link to the Creative Commons licence, and indicate if changes were made. The images or other third party material in this article are included in the article's Creative Commons licence, unless indicated otherwise in a credit line to the material. If material is not included in the article's Creative Commons licence and your intended use is not permitted by statutory regulation or exceeds the permitted use, you will need to obtain permission directly from the copyright holder. To view a copy of this licence, visit http://creativecommons.org/licenses/by/4.0/.

\section{References}

Allen, A., Kannis-Dymand, L., \& Katsikitis, M. (2017). Problematic internet pornography use: The role of craving, desire thinking, and metacognition. Addictive Behaviors, 70, 65-71.

American Psychiatric Association. (2013). Diagnostic and statistical manual of mental disorders (fifth ed.). Arlington, VA: American Psychiatric Publishing.

Andreassen, C. S., Griffiths, M. D., Pallesen, S., Bilder, R. M., Torsheim, T., \& Aboujaoude, E. (2015). The bergen shopping addiction scale: Reliability and validity of a brief screening test. Frontiers in Psychology, 6 , 1374.

Beaton, D. E., Bombardier, C., Guillemin, F., \& Ferraz, M. B. (2000). Guidelines for the process of cross-cultural adaptation of self-report measures. Spine, 25, 3186-3191.

Blaine, S. K., Nautiyal, N., Hart, R., Guarnaccia, J. B., \& Sinha, R. (2018). Craving, cortisol and behavioral alcohol motivation responses to stress and alcohol cue contexts and discrete cues in binge and non-binge drinkers. Addiction Biology, 24, 1-13.

Bozdag, Y., \& Yalcınkaya-Alkar, Ö. (2018). Adaptation of Bergen Shopping Addiction Scale to the compulsive online shopping behavior. Dependency Journal, 19(2), 23-34.

Bozkurt, H., Şahin, S., \& Zoroğlu, S. (2016). Internet addiction: A current review. Journal of Contemporary Medicine, 6(3), 235-247.

Buyukozturk, Ș. (2010). Manual of data analysis for social sciences (in Turkish). Ankara: Pegem Publishing.

Chen, L., Ding, C., Jiang, X., \& Potenza, M. N. (2018). Frequency and duration of use, craving and negative emotions in problematic online sexual activities. Sexual Addiction \& Compulsivity, 25(4), 396-414.

Clement, J. (2018). E-commerce share of total global retail sales from 2015 to 2021. Statista. Retrived February 14, 2021, from: https://www.statista.com/statistics/534123/e-commerce-share-of-retail-sales-worldwide/.

Cokluk, Ö., Sekercioglu, G., \& Buyukozturk, Ș. (2012). Multivariate SPSS and LISREL applications for social sciences (in Turkish). Ankara: Pegem Publishing.

Comrey, A. L. (1988). Factor-analytic methods of scale development in personality and clinical psychology. Journal of Consulting and Clinical Psychology, 56(5), 754-761.

Cornil, A., Long, J., Rothen, S., Perales, J. C., de Timary, P., \& Billieux, J. (2019). The gambling craving experience questionnaire: psychometric properties of a new scale based on the elaborated intrusion theory of desire. Addictive Behaviors, 95, 110-117.

Doğan-Keskin, A., \& Günüç, S. (2017). Testing models regarding online shopping addiction. Addicta: The Turkish Journal on Addictions, 4(2), 221-242.

Dong, G., Wang, M., Liu, X., Liang, Q., Du, X., \& Potenza, M. N. (2020). Cue-elicited craving-related lentiform activation during gaming deprivation is associated with the emergence of Internet gaming disorder. Addiction Biology, 25, e12713.

Faber, R. J. (1992). Money changes everything: Compulsive buying from a biopsychosocial perspective. American Behavioral Scientist, 35(6), 809-819. 
Fernandez, D., Kuss, D. J., \& Griffiths, M. D. (2020). Short-term abstinence effects across potential behavioral addictions: A systematic review. Clinical Psychology Review, 76, 101828.

Flannery, B. A., Volpicelli, J. R., \& Pettinati, H. M. (1999). Psychometric properties of the penn alcohol craving scale. Alcoholism, Clinical and Experimental Research, 23(8), 1289-1295.

Gençöz, T. (2000). Pozitif ve Negatif Duygu Ölçeği: Geçerlik ve güvenirlik çalıșması. Türk Psikoloji Dergisi, 15(46), 19-26.

Granero, R., Fernández-Aranda, F., Steward, T., Mestre-Bach, G., Baño, M., del Pino-Gutiérrez, A., et al. (2016). Compulsive buying behavior: Characteristics of comorbidity with gambling disorder. Frontiers in Psychology, 7, 625.

Grant, J. E., Potenza, M. N., Weinstein, A., \& Gorelick, D. A. (2010). Introduction to behavioral addictions. American Journal of Drug and Alcohol Abuse, 36(5), 233-241.

Griffiths, M. (2005). A "components" model of addiction within a biopsychosocial framework. Journal of Substance Use, 10(4), 191-197.

Hartston, H. (2012). The case for compulsive shopping as an addiction. Journal of Psychoactive Drugs, 44(1), 64-67.

Holden, C. (2010). Behavioral addictions debut in proposed DSM-V. Science, 327(5968), 935.

Hu, L., \& Bentler, P. M. (1999). Cutoff criteria for fit indexes in covariance structure analysis: Conventional criteria versus new alternatives. Structural Equation Modeling, 6(1), 1-55.

Joukanen, K. (2019). Impulse buying behavior and post-purchase feelings: A study on Finnish consumers (Master's thesis). Faculty of Social Sciences: Business and Economics Åbo Akademi University, Finland.

Joyner, M. A., Gearhardt, A. N., \& White, M. A. (2015). Food craving as a mediator between addictive-like eating and problematic eating outcomes. Eating Behaviors, 19, 98-101.

Kaur, M., Maheshwari, S. K., \& Kumar, A. (2019). Compulsive buying behavior and online shopping addiction among health science teachers. International Journal of Nursing Care, 7(1), 74-80.

Kelloway, E. K. (2015). Using Mplus for structural equation modeling: A researcher's guide (2nd ed.). New York: Sage.

Kline, P. (1994). An easy guide to factor analysis. Abingdon: Routledge.

Kline, R. B. (2011). Principles and practice of structural equation modeling (3rd ed.). New York and London: The Guilford Press.

Kukar-Kinney, M., Scheinbaum, A. C., \& Schaefers, T. (2016). Compulsive buying in online daily deal settings: An investigation of motivations and contextual elements. Journal of Business Research, 69(2), 691-699.

Kutlu, M., Savc1, M., Demir, Y., \& Aysan, F. (2016). Turkish adaptation of young's internet addiction test-short form: A reliability and validity study on university students and adolescents. Anatolian Journal of Psychiatry, 17(supplement 1), 69-76.

Kyrios, M., Trotzke, P., Lawrence, L., Fassnacht, D. B., Ali, K., Laskowski, N. M., \& Müller, A. (2018). Behavioral neuroscience of buying-shopping disorder: A review. Current Behavioral Neuroscience Reports, 5(4), 263-270.

Leung, L., \& Liang, J. (2019). Psychological traits, addiction symptoms, and feature usage as predictors of problematic smartphone use among university students in China. In Substance abuse and addiction: Breakthroughs in research and practice (pp. 321-341). Pennsylvania, PA: IGI Global.

Love, A., James, D., \& Willner, P. (1998). A comparison of two alcohol craving questionnaires. Addiction, 93, 1091-1102.

Luo, S., Gu, B., Wang, X., \& Zhou, Z. (2018). Online compulsive buying behavior: The mediating role of selfcontrol and negative emotions. In International Conference on Internet and e-Business (pp. 65-69). Guangzhou, China: South China University of Technology. https://doi.org/10.1145/3230348.3230397.

Manchiraju, S., Sadachar, A., \& Ridgway, J. L. (2017). The Compulsive Online Shopping Scale (TCOSS): Development and validation using panel data. International Journal of Mental Health and Addiction, 15(1), 209-223.

Maraz, A., Griffiths, M. D., \& Demetrovics, Z. (2016). The prevalence of compulsive buying in non-clinical populations: A systematic review and meta-analysis. Addiction, 111, 408-419.

Marks, I. (1990). Behavioural (non-chemical) addictions. British Journal of Addiction, 85(11), 1389-1394.

Mattos de, C. N., Kim, H. S., Filomensky, T. Z., \& Tavares, H. (2019). Development and validation of the compulsive-buying follow-up scale: A measure to assess treatment improvements in compulsive buying disorder. Psychiatry Research, 282, 112009.

Meydan, C. H., \& Șeșen, H. (2011). Yapısal eşitlik modellemesi AMOS uygulamaları. Ankara: Detay Yayıncılık.

Müller, A., Mitchell, J. E., \& de Zwaan, M. (2015). Compulsive buying. American Journal on Addictions, 24(2), $132-137$.

Müller, A., Brand, M., Claes, L., Demetrovics, Z., De Zwaan, M., Fernández-Aranda, F., et al. (2019). Buyingshopping disorder - Is there enough evidence to support its inclusion in ICD-11? CNS Spectrums, 24(4), 1-6. 
Muthén, L. K., \& Muthén, B. O. (2002). How to use a Monte Carlo study to decide on sample size and determine power. Structural Equation Modeling, 9(4), 599-620.

Nebioglu, M., Konuk, N., Akbaba, S., \& Eroglu, Y. (2012). The investigation of validity and reliability of the Turkish version of the Brief Self-Control Scale. Bulletin of Clinical Psychopharmacology, 22(4), 340-351.

Noël, X., Brevers, D., \& Bechara, A. (2013). A neurocognitive approach to understanding the neurobiology of addiction. Current Opinion in Neurobiology, 23(4), 632-638.

Pawlikowski, M., Altstötter-Gleich, C., \& Brand, M. (2013). Validation and psychometric properties of a short version of Young's Internet Addiction Test. Computers in Human Behavior, 29(3), 1212-1223. https://doi. org/10.1016/j.chb.2012.10.014.

Raykov, T., \& Marcoulides, G. A. (2008). An introduction to applied multivariate analysis. New York: Routledge.

Ridgway, N. M., Kukar-Kinney, M., \& Monroe, K. B. (2008). An expanded conceptualization and new measure of compulsive buying. Journal of Consumer Research, 35(4), 622-639.

Rose, S., \& Dhandayudham, A. (2014). Towards an understanding of Internet-based problem shopping behaviour: The concept of online shopping addiction and its proposed predictors. Journal of Behavioral Addictions, 3(2), 83-89.

Rosenberg, K. P., \& Feder, L. C. (2014). An introduction to behavioral addictions. In K. P. Rosenberg \& L. C. Feder (Eds.), Behavioral addictions: Criteria, evidence, and treatment (pp. 1-17). Cambridge: Academic Press.

Sauvaget, A., Jiménez-Murcia, S., Fernández-Aranda, F., Granero, R., Grall-Bronnec, M., Victorri-Vigneau, C., et al. (2017). A comparison of treatment-seeking behavioral addiction patients with and without Parkinson's disease. Frontiers in Psychiatry, 8, 214.

Savci, M. (2019). Validity and reliability of the smartphone craving scale: modifying and adaptation of the penn alcohol craving scale to the Turkish culture as smartphone craving scale. Anatolian Journal of Psychiatry, 20(Supplement 1), 5-14.

Savci, M., \& Aysan, F. (2019). A hypothetical model proposal for social connectedness in adolescents. Turkish Psychological Counseling and Guidance Journal, 9(54), 589-621.

Savci, M., \& Griffiths, M. D. (2019a). The development of the Turkish Social Media Craving Scale (SMCS): A validation study. International Journal of Mental Health and Addiction. Advanced online publication. https://doi.org/10.1007/s11469-019-00062-9.

Savci, M., \& Griffiths, M. D. (2019b). The development of the Turkish Craving for Internet Gaming Scale (CIGS): A validation study. International Journal of Mental Health and Addiction. Advanced online publication. https://doi.org/10.1007/s11469-019-00114-0.

Schermelleh-Engel, K., Moosbrugger, H., \& Müller, H. (2003). Evaluating the fit of structural equation models: Tests of significance and descriptive goodness-of-fit measures. Methods of Psychological Research Online, $8(2), 23-74$.

Schumacker, R. E., \& Lomax, R. G. (2004). A beginner's guide to structural equation modeling (2nd ed.). New Jersey: Lawrence Erlbaum Associates.

Shanthi, R., \& Desti, K. (2015). Consumers' perception on online shopping. Journal of Marketing and Consumer Research, 13, 14-21.

Şimșek, Ö. F. (2007). Yapısal eşitlik modellemesine giriş: Temel ilkeler ve LISREL uygulamaları. Ankara: Ekinoks Yayıncilı.

Starcke, K., Schlereth, B., Domass, D., Schöler, T., \& Brand, M. (2012). Cue reactivity towards shopping cues in female participants. Journal of Behavioral Addictions, 2(1), 17-22.

Starcke, K., Antons, S., Trotzke, P., \& Brand, M. (2018). Cue-reactivity in behavioral addictions: A metaanalysis and methodological considerations. Journal of Behavioral Addictions, 7(2), 227-238.

Sümer, N. (2000). Yapısal eșitlik modelleri: Temel kavramlar ve örnek uygulamalar. Türk Psikoloji Yazıları, 3(6), 49-74.

Tabachnick, B. G., \& Fidell, L. S. (2013). Using multivariate statistics (Sixth ed.). Cranbury: Pearson Education.

Tang, D., Yang, Y., Yan, Y., \& Zhou, M. (2014). What determines online consumers to migrate from PC to Mobile Terminals? In An empirical research on consumers' online channel-migration behaviors. Wuhan: Paper presented at the Wuhan International Conference on e-Business. https://aisel.aisnet.org/whiceb2014/ 36.

Tangney, J. P., Baumeister, R. F., \& Boone, A. L. (2004). High self-control predicts good adjustment, less pathology, better grades, and interpersonal success. Journal of Personality, 72(2), 271-324.

Tanoto, S. (2019). Financial knowledge, financial wellbeing, and online shopping addiction among young Indonesians. Jurnal Manajemen dan Kewirausahaan, 21(1), 32-40.

Tao, A., Moreno, A., \& Morgan, S. (2019). Click bait: Problematıc internet pornography use among older adults: Session 305. American Journal of Geriatric Psychiatry, 27(3), 24-25. 
Thompson, B. (2004). Exploratory and confirmatory factor analysis: Understanding concepts and applications. Washington, DC: American Psychological Association.

Trotzke, P., Starcke, K., Müller, A., \& Brand, M. (2015). Pathological buying online as a specific form of Internet addiction: A model-based experimental investigation. PLoS One, 10(10), 1-17.

Trotzke, P., Starcke, K., Müller, A., \& Brand, M. (2019). Cue-induced craving and symptoms of online-buyingshopping disorder interfere with performance on the Iowa Gambling Task modified with online-shopping cues. Addictive Behaviors, 96, 82-88.

Turel, O., \& Bechara, A. (2016). Social networking site use while driving: ADHD and the mediating roles of stress, self-esteem and craving. Frontiers in Psychology, 7, 455.

Turkish Statistical Institute. (2017). Household information technology usage research. Ankara: Turkish hanehalkı bilișim teknolojileri kullanım araștırması, TUIK.

Uğur, E. (2019). Online alıșveriș bağımlılı̆̆ı. In M. Savcı, M. Ercengiz, \& F. Aysan (Eds.), Problemli teknoloji kullanımı (pp. 177-205). Ankara: Pegem Akademi.

Varo, C., Murru, A., Salagre, E., Jiménez, E., Solé, B., Montejo, L., Carvalho, A. F., Stubbs, B., Grande, I., Martínez-Arán, A., Vieta, E., \& Reinares, M. (2019). Behavioral addictions in bipolar disorders: A systematic review. European Neuropsychopharmacology, 29(1), 76-97.

Villella, C., Martinotti, G., Di Nicola, M., Cassano, M., La Torre, G., et al. (2011). Behavioural addictions in adolescents and young adults: Results from a prevalence study. Journal of Gambling Studies, 27(2), 203214.

Volpe, U., Del'Osso, B., Fiorillo, A., Mucic, D., \& Aboujaoude, E. (2015). Internet-related psychopathology: Clinical phenotypes and perspectives in an evolving field. Journal of Psychopathology, 21(4), 406-414.

Watson, D., Clark, L. A., \& Tellegen, A. (1988). Development and validation of brief measures of positive and negative affect: The PANAS scales. Journal of Personality and Social Psychology, 54(6), 1063-1070.

Weinstein, A., Maraz, A., Griffiths, M. D., Lejoyeux, M., \& Demetrovics, Z. (2016). Shopping addiction and compulsive buying: Features and characteristics of addiction. In V. Preedy (Ed.), The neuropathology of drug addictions and substance misuse (vol. 3, pp. 993-1008). London: Academic Press.

Yau, M. Y. H., \& Potenza, M. N. (2015). Gambling disorder and other behavioral addictions: Recognition and treatment. Harvard Review of Psychiatry, 23(2), 134-146.

Young, K. S. (1998). Caught in the net: How to recognize the signs of internet addiction and a winning strategy for recovery. New York:John Wiley \& Sons.

Zhao, H., Tian, W., \& Xin, T. (2017). The development and validation of the Online Shopping Addiction Scale. Frontiers in Psychology, 8, 735.

Publisher's NotePublisher's Note Springer Nature remains neutral with regard to jurisdictional claims in published maps and institutional affiliations.

\section{Affiliations}

\section{Mustafa Savci $^{1} \cdot$ Erol Ugur $^{2} \cdot$ Mustafa Ercengiz $^{3} \cdot$ Mark D. Griffiths $^{4}$}

Mustafa Savci

msavci@firat.edu.tr

Erol Ugur

eugur@sakarya.edu.tr

Mustafa Ercengiz

mercengiz@agri.edu.tr

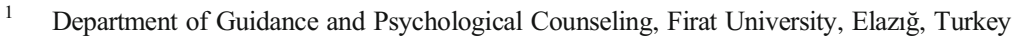

2 Department of Guidance and Psychological Counseling, Sakarya University, Sakarya, Turkey

3 Department of Guidance and Psychological Counseling, Agri Ibrahim Cecen University, Agri, Turkey

4 International Gaming Research Unit, Psychology Department, Nottingham Trent University, 50

Shakespeare Street, Nottingham NG1 4FQ, UK 